\title{
ACTIVATION OF EDUCATIONAL AND EDUCATIONAL ACTIVITIES OF STUDENTS
}

\author{
S.E. Gazizova ${ }^{1}$ \\ E.R. Gazizov ${ }^{2}$ \\ N. G. Kiseleva ${ }^{3}$
}

A. N. Zinnatullina ${ }^{4}$

\begin{abstract}
Students' activity in educational activities depends on their interest in learning. Students' interest in the subject is associated with an understanding of its significance for the future profession. To interest a student in a subject under study is a rather complicated process. For the interconnected activities of the teacher and student, it is necessary to use various teaching methods. Training is a focused pedagogical process that has been designed in advance. The learning process is associated with movement, that is, from the solution of one set educational task, a transition to another occurs, thereby promoting the student along the path of knowledge: the transition from ignorance to knowledge, from incomplete knowledge to a more
\end{abstract}

complete and accurate one. Cognitive interest plays an important role in the student's activity, emotionally colors all his educational activities. The intensification of educational and cognitive activities of students is aimed at obtaining strong and stable knowledge. To highly motivate the student to gain knowledge, he must have a well-formed image of his future profession. An indicator of the student's relationship with the subject of his activity is activity. Activation of educational and cognitive activities of students remains the main problem in the educational process. Educational and cognitive activity of students implies the development of independence and creative activity in the learning process. The activity of students implies the

\footnotetext{
${ }^{1}$ Kazan Federal University, E-mail: silmaril92@mail.ru;

${ }^{2}$ Kazan State Agrarian University, E-mail: gazizov.e@bk.ru;

${ }^{3}$ Kazan State Agrarian University, E-mail: tng1975@mail.ru

${ }^{4}$ Kazan State Agrarian University, E-mail: zinnatullina-alsu @ mail.ru
} 
awareness of the fulfillment of educational tasks, the systematic nature of training, the desire to increase the level of knowledge and others [1].

Keywords: activity, activity, motivation, interest, learning, process, knowledge.

\section{Introduction}

Human activity always has a direction and purpose. Activity is a single system of actions that are motivated by a motive. The activity of human activity generates cognitive interest. Cognitive activity of a person is a process of interaction of external and internal factors. A student cannot influence external factors communication, encouragement, teaching style, teaching methods, but they can affect his cognitive activity. The student is able to exert a volitional influence on the formation of internal factors - interest, self-control, selfesteem, independence, thinking, determination.

Cognitive activity of a person is a conscious activity aimed at the acquisition of information, the formation of knowledge and experience. A student in the process of cognitive activity performs the following actions: listens to lectures, works with a textbook, solves problems, etc. Each of these actions has a positive effect on the processes of thinking, imagination, memory, attention, which are necessary in the educational process. Among all cognitive processes, the leading one is thinking. Thinking accompanies all other cognitive processes and determines their character and quality. Particular attention is paid by the teacher to the use of methods and techniques that require active mental activity - to see the problem, simulate the situation, be able to conduct dialogue, discussion.

The system of work of the teacher to enhance the educational activities of students must be built taking into account the gradual and purposeful achievement of the desired goal - the development of cognitive and practical abilities of students.

\section{Methods.}

An important way to improve the quality of student learning is to generate interest in learning. For the development of cognitive interest in the studied material, subject, the 
methodology of teaching this material is of great importance.

Teaching methods is a system of sequential interconnected actions of a teacher and students, ensuring the assimilation of explained material. The teaching methods distinguish techniques - elements of the method, individual steps in the implementation of the methods.

Active cognitive activity must be organized from the very beginning of the lesson, since the further continuation of the lesson depends on the initial organization, on the ability to control the attention of students. The most effective method of activating the educational and cognitive activity of students is the nontraditional beginning of the lesson attracting the attention of students (quote from fiction, proverb, epigraph, video clip, rebus, riddle, folk signs, etc.).

A lecture is a leading form of the educational process. In this case, it is possible to achieve the activation of students, if throughout the lecture in any way independent intensive work of each student is ensured. One of the effective methods is considered to be a control test of the knowledge of all students at the end of the lecture [2].
Reception "echo" - clarification of information. Important points of the lecture the teacher asks students to repeat his statements in arbitrary form with a few phrases. This method will help the teacher make a conclusion, as far as his students understand, and also focus on the most important points of the lecture material.

Inspection of the material can also be used to activate students. In this case, the compendium is a written text, stimulates the student to attentive listening. Students must have a sound writing skills. The use of this method is important in case of problems with the educational literature.

Reception of "resume" - the lecturer offers students to reproduce the lecturer's words in abbreviated form at the end of the lecture. A compressed generalized material-lecture is convenient to use when discussing any problems.

Control questions are considered effective in checking the mastery of lecture material. Students are asked questions to which they must give unambiguous answers, i.e. date, name, surname, etc. Switching from one type of activity to another activates attention, 
and also relieves the tension created during the work.

Reception "memory failure" is a pre-planned forgetting by the teacher of enough obvious facts for the audience: formula, last name, term and etc. with a request to help him to recall.

Laboratory or practical training - the activity of students is achieved by independently completing assignments according to a predetermined plan under the constant supervision of a teacher. In this method, students comprehend, detail, and consolidate new educational material obtained at a lecture in a generalized form.

The method of "deliberate mistake" consists in the students finding errors in the presentation of the material studied. Errors are recorded on previously prepared sheets of paper, which at the end of the lesson are handed over to the teacher for verification.

The most modern form of active methods is interactive methods ("Inter" means reciprocal, "act" means act). Interaction methods, that is, trainees are in conversation mode. Interactive learning is, first of all, interactive learning. The essence of the interactive teaching method can be explained by a
Chinese parable: "Tell me - and I will forget; show me - and I will remember; let me do it, and I will understand" $[4,6]$.

The game method is a type of activity aimed at organizing training, as well as at the upbringing and development of personality. This method is carried out by the teacher according to a pre-planned scenario and rules through immersion in a specific situation. This method is initially motivated for success, since it involves the most active position of the students themselves.

A heuristic conversation makes it easy to find contact with students, to call out their location, and to present the studied material interestingly and vividly, thereby helping to assimilate it [5].

The method of discussion is the transition from a monological interaction to a logical one. Dialogue means communication between two persons. The teacher in the learning process creates a situation, a problem that he can solve only by involving another person (interlocutor) in this activity. Thus, communication develops in the direction of solving this situation until it is resolved. This transition contributes to the self-realization of all participants in 
the dialogue. Students can express their opinions and listen to the opinions of other speakers.

Olympiads and scientific and technical conferences are an active form of learning, in the process of preparation for which students independently conduct an active search for facts on given topics.

The test is one of the methods of activating students. The test allows the teacher to diagnose student training. In this case, a large number of students are encompassed, and the assessment is minimally subjective $[6,9]$.

The seminar refers to active learning in the event that all students were involved as speakers or speakers.

Coursework - an independent method of scientific research. These works are practiced at the university only from the second year. The student is given a specific topic on which he explores the necessary literature and conducts independent scientific research. In the future, with the disclosure of the topic and with the coincidence of topics, this term paper can be used when writing a thesis.

Thesis (final qualification work) - independent scientific and methodological research. Under the supervision of a supervisor, graduate students complete their thesis. The student in this work systematizes and consolidates the knowledge, skills and abilities gained during the study of theoretical and practical classes, shows the level of qualification obtained.

The research work of students (NIRS) is characteristic of any higher educational institution, since it is part of the educational program. In this type of work, the student reveals his creative potential, and also demonstrates his individual abilities. With the close interaction of the student and teacher, a more in-depth study of the material occurs [7-8].

Manufacturing practice is an active student activity. When a student is assigned to any position, he bears responsibility and is forced to make decisions on his own; active training takes place.

Activation of the educational and cognitive activity of a student without the development of his cognitive interest is not possible, therefore, in the learning process, it is necessary to systematically stimulate, develop and strengthen their cognitive interest. 
Cognitive activity and independence are closely related to each other, and at the same time, these two interrelated concepts complement each other. Usually, elements of student activity are already manifested in independent actions, and vice versa, the manifestation of activity directs personal independence [10].

\section{Results}

The educational process is learning, communication, as a result of which the assimilation of a specific activity occurs. The learning process is a two-way process, in which both the teacher and the student participate, but the activation of the educational and cognitive activities of students primarily depends on the teacher. The educational material itself, as a rule, does not activate cognitive processes, the emotional response of students. For students to be interested in the subject, the teacher needs to be creative, as he designs, modernizes various games and techniques for activating students. The success of training, on the other hand, depends on the development of the student's cognitive abilities - attention, memory, imagination, perception, etc.
The problem of activating the educational and cognitive activities of students is relevant. To date, there is no consensus on the understanding and methods of enhancing the educational and cognitive activities of students. There are many methods for enhancing the cognitive activity of students. Their number is equivalent to the number of people occupied with this problem.

\section{Bibliography}

Schukina G.I. The problem of cognitive interest in pedagogy / G.I. Schu-kina - M $\therefore$ Pedagogy, 2011. -- 350 p.

Kiseleva N.G., Zinnatullina A.N. Theoretical and practical thinking // Materials of the international scientificpractical conference of the Institute of Mechanization and Technical Service "Current status, problems and prospects for the development of mechanization and technical service of the agroindustrial complex". - Kazan: Kazan State Agrarian University publishing house, 2018.S. 158-160.

Kiseleva N.G., Zinnatullina A.N. Technology of problem education at the university // Materials of the II 
International

scientific-practical

conference "Actual problems of physical and mathematical education". - Nab. Chelny: NGPU, 2017 .-- 122-124 p.

Kiseleva N.G., Zinnatullina A.N. Technology of problematic education in the university Materialy II Mezhdunarodnoy nauchnoprakticheskoy konferentsii "Aktual'nyye problemy fiziko-matematicheskogo obrazovaniya" [Materials of the II International Scientific and Practical Conference "Actual problems of physics and mathematics education"]. Nab. Chelny, 2017, pp. 122-124. (In Russian).

Kiseleva N.G., Zinnatullina A.N. Interactive technologies of education // Materials of the international scientificpractical conference "Agrarian science of the XXI century. Actual research and prospects". - Kazan: Kazan State Agrarian University publishing house, 2016 - 288 p.

4. Kiseleva N.G., Zinnatullina A.N. Interactive learning technologies Materialy mezhdunarodnoy nauchnoprakticheskoy konferentsii "Agrarnaya nauka XXI ve-ka. Aktual'nyye issledovaniya i perspektivy "[Materials of the international scientific and practical conference" Agrarian science of the XXI century. Actual research and prospects"]. Kazan, 2016, pp. 288 (In Russian).

Gazizov E.R., Gazizova S.E., Kiseleva N. G., Zinnatullina A. N. Heuristic methods for solving the creative problems Revista Publicando, 5 No 17. 2018, 222-227. ISSN 1390-9304

Montgomery S.M. and Fogler H.S., “A classification scheme for interactive computer-aided insstrucnional software”, J. Eng. Educ., January 1996. Lucas R.W. The Creative Training Idea Book: Inspired Tips and Techniques for Engaging and Effective Learning [Text] R.W. Lucas. - NY: AMACOM, 2003. 470 pp. - ISBN 0-8144-0733-1

Snow R. and Farr M., Aptitude, Learning and Instruction. Vol. 3: Cognitive and Affective Process Analysis. Erlbaum, Hillsdale, NJ, 1987.

Carpenter S. K., Pashler H., Wixted J. T. \& Vul E. (2008). Theeffects of tests on 
Periódico do Núcleo de Estudos e Pesquisas sobre Gênero e Direito

Centro de Ciências Jurídicas - Universidade Federal da Paraíba V. 8 - N 06 - Ano 2019 - Special Edition ISSN | 2179-7137 | http://periodicos.ufpb.br/ojs2/index.php/ged/index

learning and forgetting. Memory \&

ognition,36, 438-448.

Cepeda N. J., Coburn N., Rohrer D.,

Wixted J. T., Mozer M. C. \& Pashler H.

(2009). Optimizing distributed practice:

Theoretical analysis and practical implications. Experimental Psychology,

$56,236-246$ 